\title{
Centralization of School Finance in Michigan
}

\author{
Paul N. Courant \\ Susanna Loeb
}

\begin{abstract}
School finance reform in Michigan involved centralization (at the state level) of spending decisions about schools, a large tax shift (mostly from property to sales), and a small tax cut. The changes came about after two decades of failed attempts to reduce property taxes in the state, and were the immediate result of an unlikely piece of legislation that abolished all funding for public schools. Unlike most centralized systems, foundation grants in Michigan differ by district. Distributionally, the reforms favor residents of small, rural districts (whose spending was increased sharply). Residents of poorer urban areas, including Detroit, lost net income as a result of the reforms, as did residents of some of the richest suburbs in the state. Michigan permits a number of districts to supplement their foundation grants by limited amounts, a strategy that we argue may be a promising way of combining the efficiency benefits of local control with the equity benefits of foundation grant systems.
\end{abstract}

\section{INTRODUCTION}

Between the 1993-1994 school year and the 1994-1995 school year the financing and fiscal autonomy of public schools in Michigan changed radically. The changes were of three types:

- The system became highly centralized at the state level. Except for in a small number of districts, local spending per pupil is now determined at the state level. Moreover, even where there is some remaining local autonomy, the state determines a maximum level of permitted spending. Those districts that spent the most before reform still spend the most.

- Local property taxes were sharply reduced, and a variety of state taxes (most notably the sales tax) were increased. The net effect was a tax reduction. 
- Spending per pupil was substantially increased in districts (generally relatively poor) where it had been lowest, and was approximately unchanged from pre-reform levels (in real terms) in all of the other districts. In combination with the overall tax reduction, increases in average spending per pupil imply other elements of state spending are lower than they would have been.

In the context of Michigan's political history around school finance and property taxation, each of the major features of the reform was crucial to its political success. In principle, however, the three are separable, and it is important to recognize this. It is quite possible, for example, to reduce reliance on property taxes without eliminating local fiscal autonomy, just as it is quite possible to eliminate local autonomy without changing the mix of taxes to support schools. Similarly, the state could provide increased support to lowspending districts without also dictating the spending levels in all districts. What Michigan got was a tax shift, a shift in the locus of fiscal control, tax reduction, and a grandfathering of school spending levels with a dollop of redistribution toward (mostly) the poorest districts.

In this article, we tell a story about why all of these things happened together, make some predictions about their effects and their likely longevity, and draw some lessons for school finance in Michigan and elsewhere. We begin with a brief discussion of the circumstances that led up to the Michigan reforms. The reforms themselves, or at least parts of them, may be exportable to other states, but we will argue here that the particulars that led to radical reform of school finance in Michigan are very unlikely to occur elsewhere. We then turn to a discussion and evaluation of the reforms themselves.

\section{PROPERTY TAXES AND SCHOOL FINANCE IN MICHIGAN—A BRIEF HISTORY}

Prior to school finance reform, property taxes in Michigan accounted for an unusually high fraction of state and local revenues. In the 1990-1991 school year, for example, while overall taxes relative to personal income were about average for the United States as a whole, Michigan was third among states in the share of school spending financed locally (65.2 percent), behind New Hampshire (which has virtually no state taxes), and Oregon, which has since changed its school financing. ${ }^{1}$ Michigan property taxes as a share of personal income had risen from 4.3 percent of personal income in 1978 to 5.0 percent by 1991, while the national trend was one of reduced dependence on property taxes. By the 1990s, it had become a truism of Michigan politics that property taxes were "too high" and had to be reduced. As a political matter, school finance reform was synonymous with property tax relief. Governor John Engler, a Republican who was elected in 1990, had made a 20-percent reduction in property taxes one of his central campaign promises.

We decline to speculate on exactly why property taxes had come to be so unpopular. Michigan had (and continues to have) a relatively generous "circuit breaker," which reduces the net property tax burden on households whose taxes

${ }^{1}$ U.S. Department of Education, National Center for Education Statistics, Common Core of Data Survey. 
exceed more than 3.5 percent of their income. ${ }^{2}$ Thus, the Michigan property tax was considerably less regressive at low levels of income than are property taxes in general. Whatever the reasons, the property tax was almost universally reviled, providing motivation for the story to follow.

In addition to the property tax, other aspects of the pre-reform system of school finance were unattractive to a number of relevant constituencies that otherwise had relatively little in common. Many liberals were unhappy about the fact that there was substantial variation in spending per pupil, and that the variation was strongly correlated with school district wealth. In the 1993-1994 academic year revenues per pupil from state and local sources for general expenditures ranged from \$3404 in the Onaway Area Community School District (with a millage rate of 22.66) to $\$ 10,295$ in Bloomfield Hills (with a millage rate of 24.41). ${ }^{3}$ (Both of these millage rates were applied to State Equalized Value or SEV which is constitutionally set at one-half of market value, and which tends to be slightly less than one-half of actual market value.) Regressing spending per pupil on SEV per pupil using data from the last year prior to reform, we obtain a coefficient of 0.0092 with a standard error of 0.0004 . The relationship is statistically and economically significant. ${ }^{4}$

Meanwhile, voters and educators in richer districts were unhappy with the state aid formula, which taxed them to provide school funds for the poorer districts. Prior to reform, Michigan operated under a "power equalization" mechanism that provided state funds to lower wealth districts. Essentially, the state provided a minimum tax base per pupil (\$102,500 of SEV in 1993-1994) for all districts. Districts with SEV per pupil of less than $\$ 102,500$ were subsidized such that each mill levied would raise $\$ 102.50$ per pupil. In addition, these districts received a foundation grant of $\$ 400$ per pupil. Districts with SEV per pupil in excess of the guarantee had their foundation grants taxed

${ }^{2}$ Households with residents who are under age 65 receive a refundable tax credit of 65 percent of the taxes paid in excess of 3.5 percent of income. Households with residents who are over age 65 receive a credit of 100 percent. All are subject to a cap of $\$ 1200$ in tax credits, and the credit is phased out for incomes over $\$ 73,000$ a year. Renters are allowed to claim 17 percent of their rent as property taxes.

${ }^{3}$ These revenues include all local funds, unrestricted state funds from the power equalization mechanism (discussed later) and those state categorical grants which were included in the foundation grants under the new system (also discussed later). In our earlier study, Courant, Gramlich, and Loeb [1995], we used current operating expenditures instead of these revenues for the analyses. The measures differ primarily in that revenues include neither federal categorical grants nor a number of the restricted state grants that are part of current operating expenditures. We choose to use the revenue measure here because it is the basis used for determining funding levels under the new system and because it makes comparison of pre- and post-reform spending levels most straightforward. In addition, because the variation in federal and state categorical grants largely reflects differences in the cost of providing educational services, a measure that does not include them will provide a more accurate picture of the actual differences among districts in the level of real expenditures per pupil. The revenue measure that we use here was not available for use in our earlier study. District-level information on Michigan schools comes from The Integrated Database on Michigan Education, a continuously updated resource of the School of Education, University of Michigan.

${ }^{4}$ The economic significance is probably somewhat overstated. In an earlier study, Courant, Gramlich, and Loeb [1995], we used a method developed by Ratcliffe, Riddle, and Yinger [1990] and Downes and Pogue [1994] in order to correct for interdistrict differences in the cost of providing educational services. We found that correcting for cost factors using data from 1992-1993 lowers the univariate regression coefficient of per-pupil property wealth on expenditures per pupil by 12 to 23 percent, depending on specification. The relationship remains highly significant, with $t$ statistics of 20.33 to 60.77 , depending on specification. 
away unti it was exhausted, at which point they were on their own. ${ }^{5}$ Throughout the 1980s and 1990s, the number of districts that received positive state aid under the power equalization system had been falling [Fisher and Wassmer, 1995]. By 1993-1994, over 39 percent of districts, with nearly 42 percent of all students, were above the minimum tax base, and had some or all of their foundation grants taxed away. These "out-of-formula" districts were generally not strong supporters of the pre-reform system of state aid.

Finally, during 1992-1993, the small, rural, and low-spending school district of Kalkaska had to shut down, unable to persuade its voters to approve an operating millage. The incident received national attention, and reinforced the widely held view in the state that the system of school finance was in need of major repairs.

Michigan voters and politicians were quite clear that they did not like property taxes and that there were other weaknesses in the school finance system, but they were unclear on what to do about it. Between 1972 and 1993, Michigan voters rejected 12 statewide ballot proposals that would have reduced property taxes as a source of school finance. The 1993 proposal, which would have increased income taxes to replace reduced property taxes, was strongly supported by Governor John Engler, who was (and is) overwhelmingly popular. It received only 45 percent of the vote. The failure of these ballot proposals is consistent with what Cronin [1989, pp. 84-87] terms the "conventional wisdom" regarding referenda on complicated matters. Proposed changes often start out with widespread support because people do not like the status quo, and end up failing because voters understand the status quo and do not dislike it enough to exchange it for something that they do not understand.

On July 20, 1993, the alternative to reform of school finance changed from the status quo to the abolition of public schools. It is a fundamental tenet of essentially all models of choice that the alternatives matter, and it is hard to imagine a more radical revision in alternatives. The state senate was debating Governor Engler's latest proposal to reduce property taxes, via the mechanism of reducing assessment ratios. Senator Debbie Stabenow, who was an announced candidate for the Democratic gubernatorial nomination, proposed an amendment to entirely eliminate the property tax as a source of local school finance. At the time, Stabenow's move was widely interpreted as an attempt on her part to show how silly it was to cut taxes without specifying new revenues for the schools. If that was its purpose, it backfired. The senate passed the amended bill the same day, the house followed a day later, and the governor immediately announced that he would sign the bill. With little debate the state had eliminated $\$ 6.5$ billion in school taxes for the 1994-1995 school year. Absent further action, there would be no way to finance the public schools. Local school districts had been stripped of the only revenue source under their own control, and the state had put nothing else in its place.

After a fair amount of political maneuvering, the legislature and the governor agreed to present the voters with two alternative mechanisms of school finance. Contrary to many characterizations in the national press, the issue at hand was not the choice between property taxes and sales taxes. Rather, the question

\footnotetext{
${ }^{5}$ The formula was $\operatorname{aid}_{k}=\max \left(0, \$ 400+\right.$ mills $\left._{k} \times\left(\$ 102,500-A_{k}\right)\right)$, where mills $s_{k}$ is the millage rate for operating expenditures in district $k$ and $A_{k}$ is the actual SEV per pupil in the district. A district with $\$ 90,000$ in SEV per pupil would receive $\$ 12.50$ in subsidy for every mill levied. Symmetrically, a district with $\$ 115,000$ in SEV per pupil would lose $\$ 12.50$ of its foundation grant for every mill levied. If it levied more than 32 mills, it would receive no state aid.
} 
Table 1. Summary of tax changes under school finance reform plans.

\begin{tabular}{|c|c|c|c|}
\hline Tax change & Pre-reform & Statutory plan & Proposal A \\
\hline Sales and use tax & $4 \%$ & $4 \%$ & $6 \%$ \\
\hline Interstate phone calls & $0 \%$ & $4 \%$ & $6 \%$ \\
\hline Income tax & $4.6 \%$ & $6 \%$ & $4.4 \%$ \\
\hline Personal exemption & $\$ 2100$ & $\$ 3000$ & $\$ 2100$ \\
\hline Single business tax & $2.35 \%$ & $2.75 \%$ & $2.35 \%$ \\
\hline Real estate transfer tax & $0.10 \%$ & $0.75 \%$ & $0.75 \%$ \\
\hline Cigarette tax (per pack) & $\$ 0.25$ & $\$ 0.40$ & $\$ 0.75$ \\
\hline Assessment cap & no & no & $\begin{array}{l}\text { lesser of } 5 \% \text { or infla- } \\
\text { tion; adjusted to } 1 / 2 \\
\text { market value on sale }\end{array}$ \\
\hline \multicolumn{4}{|c|}{ K-12 school property taxes (mills) } \\
\hline Homestead & 34 (avg.) & 12 (local tax) & 6 (state tax) \\
\hline Second homes & 34 (avg.) & 24 (12 local $)$ & 24 (18 local $)$ \\
\hline Business & 34 (avg.) & 24 (12 local) & 24 (18 local) \\
\hline Hold-harmless mills ${ }^{\mathrm{a}}$ & & \multicolumn{2}{|c|}{$\begin{array}{l}\text { (may be levied in districts whose per-pupil } \\
\text { spending currently exceeds } \$ 6500 \text { ) }\end{array}$} \\
\hline
\end{tabular}

put before the voters on March 15, 1994, concerned the mix of revenues that would be used to replace the abolished local property tax. Voters chose between Proposal A and a "statutory plan," that, according to legislation passed on Christmas Eve, 1993, would have been implemented had Proposal A failed. The differences between the two plans are summarized in Table 1. Proposal A passed by a margin of 2 to 1 , carrying all 81 counties in the state. Although the plans differ a good deal in their sources of finance, both plans would have centralized school finance decisions and increased spending per pupil in those districts that had previously spent the least. ${ }^{6}$

\section{THE NEW SYSTEM}

The new system "solved" all of the political problems with the old: The property tax was greatly reduced, spending levels in the lowest spending districts (including troublesome Kalkaska) were increased, and all districts were guaranteed receipt of large foundation grants from the state-no one was out-of-formula anymore. Moreover, because spending in essentially all districts rose slightly or stayed the same, in real terms, the education establishment had no significant basis on which to quarrel with the reforms.

The new Michigan system of school finance has two important features that distinguish it from other state systems. First, the state provides foundation

\footnotetext{
${ }^{6}$ The discerning reader will note that among the taxes that replaced the local property tax were state and local property taxes. One reason why local taxes had to be employed in the new finance scheme was that the state was constitutionally prohibited from raising revenue by more than about $\$ 4.2$ billion, according to a provision passed in 1979 that limits state government tax revenues to 9.49 percent of personal income. See Addonizio, Kearney, and Prince [1995] for this and other details of the legal and political framework in which reform took place.
} 
grants to all districts in amounts that vary according to each district's spending in the year before reform. When the plan is fully implemented, those districts that spent the most pre-reform will receive a foundation grant that is $\$ 1500$ per pupil per year more than that received by those districts that spent the least. Second, only a small number of districts (those that spent the most pre-reform) are allowed to supplement their foundation grants, and the amount of supplementation permitted also varies by district. The combination of variable foundation grants with limited supplementation and variable supplementation turns out to have very interesting implications for the level and distribution of education spending in the state. In particular, we will argue that the Michigan reforms, in contrast both to uniform foundation grants and to systems that would allow unlimited supplementation, are likely to lead to a higher level of spending overall. Before explaining the reasoning behind these conclusions, we need to spend a little time on the details of the new system. ${ }^{7}$

\section{Expenditures}

The new finance system is a modified foundation grant system, in which the state provides an operating grant to each district. In 1994-1995, the first year of the new system, districts were divided into three groups for the purpose of determining their foundation grants.

- The $29 \mathrm{~K}-12$ districts $(48,659$ students) that spent less than $\$ 3950$ per pupil in 1993-1994 were given foundation grants of $\$ 4200$.

- The $454 \mathrm{~K}-12$ districts $(1,372,359$ students) that spent between $\$ 3950$ and $\$ 6500$ in 1993-1994 received foundation grants that supported increases in spending per pupil ranging from $\$ 250$ for the low-spending districts in this group to $\$ 160$ for the high-spending districts.

- The 41 remaining $\mathrm{K}-12$ districts (170,978 students) that spent more than $\$ 6500$ in 1993-1994 received $\$ 6660$ and were allowed to raise additional funds (termed "hold-harmless mills") up to the point where their total per-pupil revenue equaled their 1993-1994 revenue plus $\$ 160{ }^{8}$

In all years subsequent to 1994-1995, each district's foundation grant is computed from a formula based on the statewide basic foundation allowance, which was $\$ 5160$ per pupil in 1994-1995. The basic foundation allowance changes from year to year according to an index that we term the School Aid Fund Index (SAFI). The SAFI for year $t$ equals total statewide avenues per pupil for all taxes that are earmarked for the School Aid Fund (see the discussion of revenues that follows), divided by the 1994-1995 level of this ratio.

Over the next few years all districts with revenues less than the basic foundation allowance will be given yearly increases under a formula that allows these

\footnotetext{
${ }^{7}$ See our earlier paper, Courant, Gramlich, and Loeb [1995], for more details. See also Senate Fiscal Agency [1994].

${ }^{8}$ Only 28 of these districts raise the additional funds through local taxes. If a district has less than 350 pupils or if the tax rate they need to raise the additional funds is less than 0.05 mills, the state provides these funds. Ten of these 41 districts with a total of 1576 students have less than 350 students, and three districts with 4597 students require less than 0.05 mills. This leaves 28 districts that raise additional funds locally.
} 
districts to "catch up" to the basic foundation allowance. ${ }^{9}$ All other districts will receive their foundation grant of the year before, plus the dollar change in SAFI, which was $\$ 153$ between 1994-1995 and 1995-1996. Districts in the third group, which are allowed to raise additional funds, will be limited in their supplementation to the same nominal amount each year, the difference between their 1993-1994 expenditure level and \$6500.

The striking feature of the new system is that it tends to preserve the prereform nominal differences in spending per pupil across districts. For districts that spent more than $\$ 5000$ and less than $\$ 6500$ per pupil in 1993-1994 this tendency is exact - their foundation allowances in each year will grow by the same dollar amount. The lower spending districts will join this group after the "catch-up" period is completed at the end of the decade. Twenty-eight of the 41 highest spending districts are the only districts with choice over their spending levels, and the most they are allowed to spend will preserve their pre-reform nominal spending differences relative to other districts.

\section{Revenue Sources}

Revenues for the new system come from a variety of sources. All of the tax increases reported in Table 1 are earmarked for the state School Aid Fund. In addition, the School Aid Fund receives 60 percent of the revenues from the rest of the sales tax, 14.4 percent of state income tax collections (to be increased to 23 percent for the 1996-1997 academic year and thereafter), as well as tax revenues from liquor, industrial and commercial facilities, and the state lottery. In 1996-1997 these earmarked funds will cover approximately 88 percent of the state funds required to fund the foundation grant system. Additional funding has come from a variety of one-time sources, as well as from general revenues [Kearney, 1994; House Fiscal Agency, 1994].

For districts to participate in the new finance system and receive state funds, they must levy an 18-mill property tax on all nonhomestead property in their district. (Homestead property, under the new law, is an owner-occupant's principal residence. Nonhomestead property is all other taxable property, including rental housing.) A grandfather clause allows those 13 of the $524 \mathrm{~K}-12$ districts that levied less than 18 mills prior to reform to levy only their previous millage rate. The state supplements locally raised funds with state funds to bring district spending up to the level determined by the foundation grant formula. ${ }^{10}$

The new system represents both a tax shift and a tax cut. Property taxes were cut sharply, income taxes were reduced somewhat, and sales taxes increased but not by as much as other taxes fell. Table 2 provides detailed information on the changes in state and local revenue associated with school finance reform in 1995-1996, by which time the revenue changes are fully

\footnotetext{
${ }^{9}$ Districts that are between $\$ 4200$ and $\$ 5000$ will have their per-pupil spending increase at a considerably greater rate (up to twice) than the basic foundation allowance, until all districts reach at least the basic foundation allowance. Note that most of the low-spending districts are rural, and are also relatively low-cost districts. Thus, in real terms, the increase in spending per pupil for these districts is understated by the actual changes.

${ }^{10}$ Districts also have the option of levying three additional enhancement mills on all property in their district. For the first 3 years of the new program (until 1997-1998) they may use the revenues from these mills solely for their own purpose. After that time they must share the revenues with other districts in their intermediate school district. Intermediate school districts are approximately the size of counties.
} 
Table 2. Revenue changes from school finance reform, 1995-1996 (millions of dollars).

\begin{tabular}{lr}
\hline Property tax & $(\$ 4653)$ \\
$\quad$ Net decrease in school and other property tax & 1113 \\
New state education property tax (6 mills) & 615 \\
Reduction in property tax credit due to tax cut & $(62)$ \\
Other property tax changes & $(\$ 2988)$ \\
$\quad$ Subtotal property tax & $(\$ 293)$ \\
Reduced income tax rate & $\$ 1962$ \\
Sales and use taxes & 74 \\
$\quad$ Increased tax rates from 4 to 6 percent & $\$ 2036$ \\
$\quad$ Other sales tax changes & 387 \\
Subtotal sales and use taxes & 111 \\
Increased tobacco taxes & $(\$ 747)$ \\
Teal estate transfer tax & $\$ 380$ \\
Memorandume in state and local taxes & Estimated increase in federal taxes
\end{tabular}

Sources: Wortley and Towne [1996]; Senate Fiscal Agency [1994]; authors' calculations.

implemented. For a sense of scale, personal income in the state in 1995 was $\$ 224.7$ billion, total state and local revenue in 1995-1996 is estimated at 24.8 billion, and total local property taxes for schools in 1993-1994, the last prereform year, were $\$ 5.9$ billion [Senate Fiscal Agency, 1995, 1996]. The net property tax cut is thus on the order of 1 percent of personal income, 12 percent of state and local tax revenue, and half of pre-reform property taxes. Finally, it is worth noting that the Michigan reforms led to an increase in federal tax liabilities; by and large, deductible taxes were reduced and nondeductible taxes were increased. The Senate Fiscal Agency [1994] estimated that in 1994-1995 individual federal tax liabilities in Michigan were increased by $\$ 339$ million because of the reduction in property taxes. Scaling up to 1995-1996, the loss of deductibility is worth about $\$ 380$ billion. By choosing to substitute sales taxes for property taxes, the state reduced its revenues by about twice as much as it reduced the net taxes paid by its citizens.

\section{EFFECTS OF THE REFORMS}

Discussion of the reforms is complicated by the possibility that some of their features may not be sustainable over the long run, and that the reforms are likely to lead to changes in interdistrict distribution of property values and population. Our discussion of the distributional effects of the reforms, deriving both from changes in school spending levels and changes in tax structure, assumes that the reforms will stay in place and that households will stay put. It also ignores changes in property values. We then turn to the longer run questions, including the effects of reform on the overall level and composition of $\mathrm{K}-12$ spending in the state. Throughout, we assume that the incidence of the cut in state revenues is the same as the incidence of state spending generally (which, absent better information, we implicitly assume to be proportional to income). 


\section{Expenditures at the District Level}

Had the system been fully implemented in 1994-1995, the positive relationship between wealth and expenditures ${ }^{11}$ that we reported for 1993-1994 would be somewhat weaker, but still strong and significant. The univariate regression coefficient on wealth falls from 0.0092 (with a standard error of 0.0004) under the old system to $0.0070(0.0004)$, assuming that the new system had been fully implemented in 1994-1995. ${ }^{12}$ Mean spending per pupil was $\$ 5420$ in 1993-1994 and would have been \$5676 in 1994-1995 (the actual mean was $\$ 5500)$. Overall, the new system increased average spending and reduced the variance across districts and students; it also weakened the relationship between general operating expenditures and district property wealth. In addition, because the new system (when fully implemented) preserves nominal and not real spending differences across districts, the variance among districts will continue to drop as inflation decreases the value of the nominal differences.

The reform tends to equalize spending through the mechanism of bringing the lowest spending districts up to the level of the basic foundation allowance, while preserving the nominal difference between that level and actual spending for all other districts. Because school spending per pupil is positively correlated with income per capita, the incidence of the expenditure changes is progressive. The average median household income of the districts that received real spending increases (the districts that spent less than $\$ 5000$ per pupil in 19931994) was $\$ 27,710$ in 1990 , compared to $\$ 33,621$ for districts that spent more than $\$ 5000$. Most of the beneficiaries on the expenditure side are residents of relatively small, rural districts. Notably, four large, low-income urban districts Detroit, Grand Rapids, Flint, and Lansing-received no benefits from reform on the spending side, because they all spent more than $\$ 5000$ per pupil prior to reform. All of these districts had median incomes below $\$ 27,000$ in 1990, and all of them, being urban districts, almost certainly faced higher costs of production of educational services than did school districts on average. ${ }^{13}$

\section{Tax Incidence}

Viewed from the perspective of the state as a whole, a reduction in property taxes coupled with an increase in sales taxes would not be expected to have much effect on overall tax incidence. Except for the property tax at the lowest income levels, both taxes are somewhat regressive with respect to current

\footnotetext{
${ }^{11}$ The proxy for expenditures used in these regressions is the revenue measure discussed in footnote 3 , which explains why it is a fairly good proxy for cost-adjusted spending available to $\mathrm{K}-12$ students without special needs.

${ }^{12}$ These regressions are based on 523 of the $524 \mathrm{~K}-12$ districts in Michigan. Mackinac Island Public Schools were not included because their per-pupil property value was substantially higher than in any other district $(\$ 1,099,390$ per pupil). Although Mackinac is part of the population of Michigan school districts, the well-known power of outliers to shift regressions makes it misleading to include it in an analysis that is meant to describe overall trends in the state. With Mackinac Island included the slopes are $0.0081(0.0003)$ pre-reform and $0.0063(0.0003)$ with full implementation.

${ }^{13}$ These calculations and those in the succeeding section are based on data from the The Integrated Database on Michigan Education and from the National Center for Education Statistics School District Database, which provides decennial census data for school districts.
} 
income and approximately proportional with respect to lifetime income. ${ }^{14}$ But the property tax cut in Michigan was variable on a number of dimensions. First, homeowners generally received much larger cuts than did renters; except in the 28 districts that permit local supplementation, homestead property tax rates fell from an average of 34 mills to a uniform 6 mills. Renters did much less well; rental property is taxed as nonhomestead property, which is now taxed at 24 mills statewide. Because renters have lower incomes than homeowners, this difference in property tax cuts is plainly regressive. The regressivity of the cuts is compounded by the operation of the Michigan circuit breaker which reduced the regressivity of the pre-reform property tax, and hence reduced the progressivity of reducing the property tax. Thus, while renters pay their full share of the increased sales tax, their net tax reduction in any jurisdiction was generally smaller (as a fraction of income) than that for homeowners. As a group, renters are generally worse off as a consequence of the tax shift.

For homeowners in a given school district, the incidence of the property tax cut with respect to permanent income is approximately proportional, once the circuit breaker is taken into account. Across school districts, however, we need to look at the relationship between income and the reduction in property tax payments, which depends on the tax rate (reduced to a uniform six mills except in the districts that can levy hold-harmless millages) and the tax base. No data are available on the joint distribution of income and house value by school district. To make a rough estimate of the incidence of the property tax cuts, we calculated the average (per owner-occupied housing unit) property tax reduction in each district as a fraction of the median household income in that district. We then looked at the distribution of this statistic by income quintile, excluding the 28 highest spending districts, whose tax rates still vary. (This statistic is imperfect: It takes no account of the circuit breaker, so it overstates the magnitude of the tax cut for the lower quintiles. In addition, the median household income includes renters as well as homeowners. As long as the relationship between the median household income and the median homeowner's income does not vary too much across income quintiles, however, comparisons across quintiles will still be meaningful.)

The results are quite striking. For the bottom quintile (median household income of $\$ 18,771$ in 1990) the average property tax reduction per owneroccupied home was 2.63 percent of median income. For the other four quintiles, the average ranged from 3.23 percent to 3.78 percent, with no trend. Detroit, with a median income of $\$ 18,742$, is in the lowest quintile. The tax cut in Detroit was 1.97 percent of median income, leaving the rest of the quintile very near the average for the rest of the state. Given that sales taxes paid are approximately proportional to permanent income, we conclude that for most of the state the incidence of tax changes is approximately proportional. Citizens of Detroit, however, surely saw a considerable increase in total taxes paid.

${ }^{14}$ These conclusions are relatively uncontroversial for the sales tax [Slemrod and Bakija, 1996; Fullerton and Rogers, 1993]. There is a wider range of opinion on the property tax, but we find persuasive that the excise effects of a state or local residential property tax fall on consumption, making the relevant issue the relationship between income and housing consumption. Fullerton and Rogers find that housing consumption as a fraction of income is higher than average at the lowest income levels, and then becomes approximately proportional to income. This is roughly consistent with other theoretical and empirical work on the subject [see, for example, Ihlanfeldt, 1982]. 
At the same time, a group of the highest income citizens, residents of the 28 districts with the option to levy hold-harmless millages, also saw their total taxes increase. This group had a median household income of $\$ 36,210$ in 1990 , high in the fourth quintile of the income distribution. Their property taxes fell by about 50 percent compared to an average reduction of 82 percent for the state as a whole. The average tax cut as a fraction of median income for this group was 2.16 percent, not very different from that of the city of Detroit, at the other end of the income distribution.

\section{What Will Happen to the Basic Foundation Allowance?}

Our concern here is with the longer run. Spending in all districts in Michigan is now keyed to the basic foundation allowance. By legislation, the basic foundation allowance is determined by SAFI, but what legislation does, legislation can undo, and the trade-off between school spending and other parts of the state budget is sure to arise again in the future. To address the question of the effect of Michigan's reforms on the level of school spending in the state we draw on Loeb [1996], which shows that foundation grant systems that allow limited supplementation (as does Michigan) may avoid the most serious difficulties that arise under uniform foundation grants with no supplementation and with unlimited supplementation.

\section{Uniform Foundation Grants}

The great advantage of uniform foundation grants is that they equalize spending across districts. The great disadvantage is that they eliminate all local control. Under a system of district funding voters can, to at least some degree, "vote with their feet" and choose their district of residence to receive close to the level of spending on schools that they prefer given the tax price they must pay for education. ${ }^{15}$ Under uniform state finance, on the other hand, many voters are likely to be off their demand curve for school spending. Figure 1 illustrates the distribution of funding in Michigan prior to reform. The skewed distribution, with a number of students in high-spending districts receiving substantially more funding than the median for the state, suggests that residents of high-spending districts are especially likely to be far from their preferred spending in a system of pure state funding with equal state grants. This assumes that there is a social choice mechanism that results in grant levels close to that preferred by the median (or even the mean) voter in the state. ${ }^{16}$ As a result, a switch from local funding to uniform state funding is often

${ }^{15}$ This assumption requires, among other things, that there be many communities that individuals can choose to live in, and thus is generally more realistic for large metropolitan areas than for sparsely populated rural areas. It has some empirical support. Gramlich and Rubinfeld [1982], using data from Michigan, found evidence of such grouping of people with similar demands, especially in the urban centers. Bergstrom, Rubinfeld, and Shapiro [1982] and Rubinfeld, Shapiro, and Roberts [1987] also found evidence of Tiebout sorting in their microestimates of elasticities of demand for public school spending.

${ }^{16}$ The median-voter assumption has been both used and analyzed in numerous studies including Gramlich and Rubinfeld [1982] and Inman [1987]. Romer and Rosenthal [1982, 1979] point out potential shortcomings of the median-voter model. For the median voter to be the decisive voter the decisions must be made in single-issue majority rule processes and preferences must be singlepeaked. Courant and Rubinfeld [1987] argue that if there is logrolling the mean preference may be decisive. Even so, with a high-skewed distribution, high outliers will be far from the social choice. 


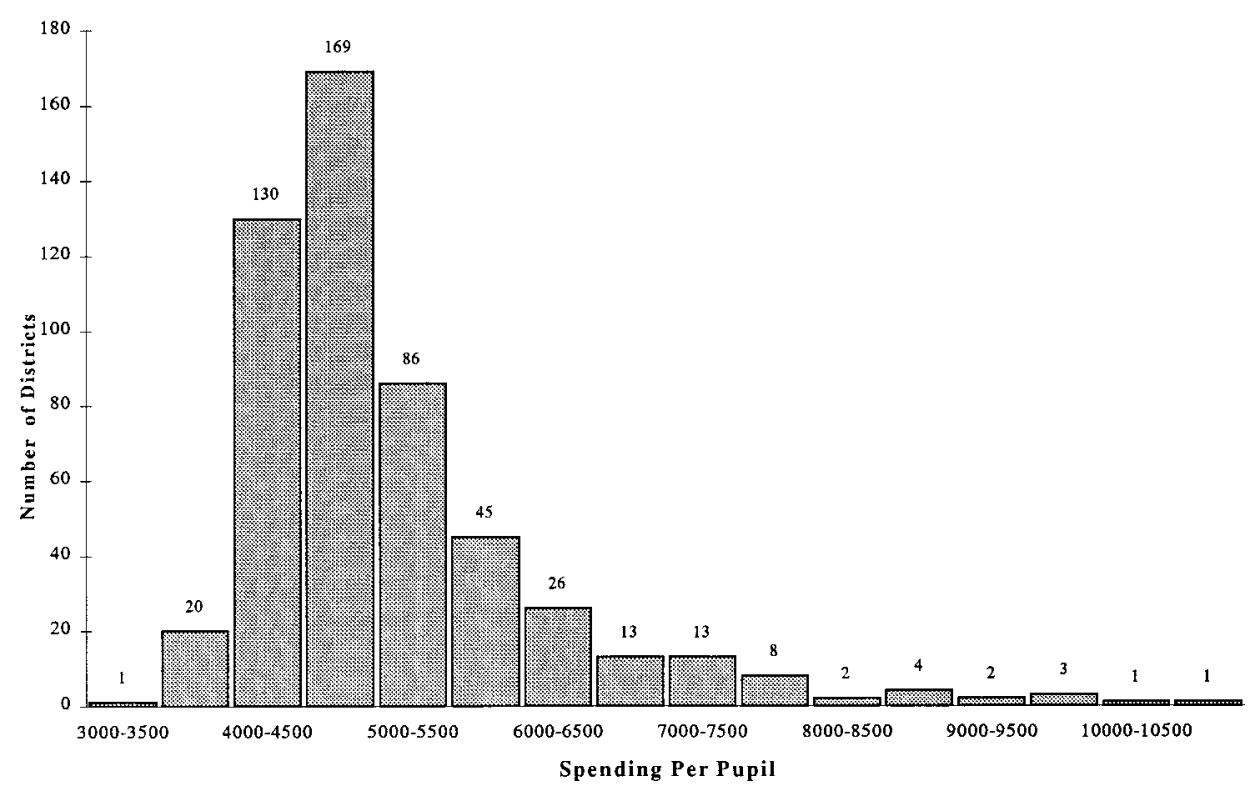

Figure 1. The distribution of per-pupil spending under the power equalization system 1993-1994 (1995 dollars).

politically difficult. Raising all school spending to the level of the highest spending district is invariably financially infeasible, whereas forcing districts to reduce spending on schools, although not impossible [see the California case as described by Downes, 1992, and Silva and Sonstelie, 1995], is likely to be unpopular especially in high-wealth, and often politically powerful, districts.

Figure 2 illustrates a case in which high-demand districts will drop out of the system altogether, and choose private schools. The level of uniform state spending (point B in the figure) is far from the level that would be chosen at the local tax price (point A). The voter-consumer depicted in Figure 2 will maximize utility by sending her child to a private school (point $\mathrm{C}$ ) even though she is still financing an expenditure of B in the public schools. Residents who choose private schools will have little incentive to support public funding for education, and will attempt to push the uniform foundation grant downward.

\section{State Grants with Unlimited Local Supplements}

The second system, equal state grants with unlimited local supplementation, has many advocates [see, for example, Ladd and Yinger, 1994]. This system has the intuitive appeal of retaining much local control over funding decisions on the margin while insuring an "adequate" level of financing for all districts. However, these ostensible benefits may not be possible to sustain, because voters from districts with high wealth are likely to press for low foundation grants (in the limit, zero) and large supplementation because (assuming that the sources of state finance are highly correlated with wealth) their tax price is lower at the district level than it is at the state level.

The problem is illustrated in Figure 3. The tax price for a dollar of spending per pupil is higher at the state than district level for residents of high-wealth 


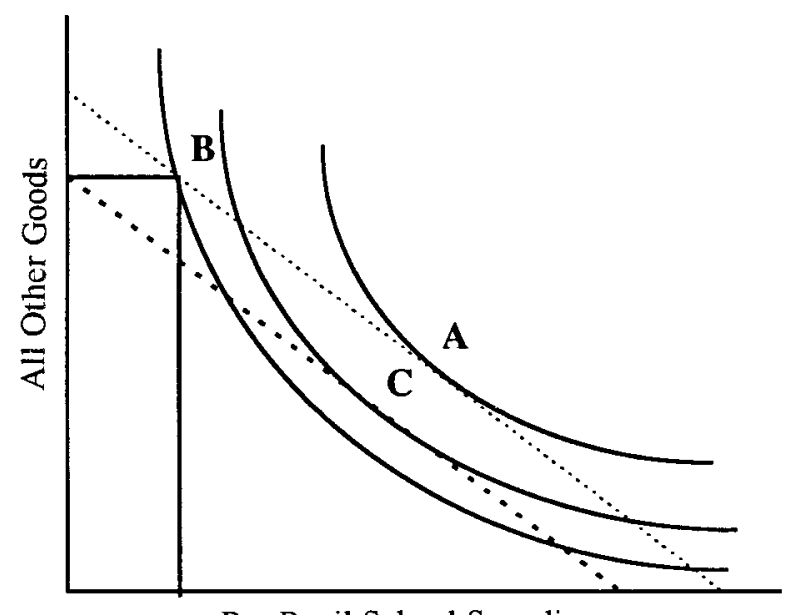

Per-Pupil School Spending

\section{A: Optimal State Funding Level \\ B: Actual Low State Funding Level \\ C: Optimal Private School Spending}

Figure 2. High-demand individuals may prefer private schooling given a system of low-uniform state grants.

districts (the dashed line in Figure 3 reflects the district tax price while the steeper, dotted line reflects the state tax price). Any positive state funding shifts the intercept of the (solid) local budget line in and thus will result in lower utility (point B) than if there were no state funding (point A). Voters whose circumstances are depicted in Figure 3 will generally support zero or low foundation grants. (This analysis assumes that voters have sufficient mobility so that voters within a district have fairly similar demands for schooling at the local tax price.)

The extent to which residents of higher wealth districts can push the foundation level down will depend on their number and political influence, but we expect that higher wealth voters have influence in higher proportion than their number. If so, state funding levels will generally be pushed even lower than the distribution of tax prices facing all potential voters would suggest, because voters from high-wealth districts will prefer lower levels of state funding while voters from low-wealth districts will prefer the same as in a pure state funding system. Thus, a system of state grants with unlimited local supplementation may allow so much local control over funding decisions that it will provide little if any cross-district equalization. Under such a system, the level of the foundation grant will generally be lower than is the case with either uniform grants or limited supplementation.

\section{Limited Local Supplementation}

Finally, consider systems of foundation grants with limited local supplementation. Again, voters from low-wealth districts will prefer that funding come 


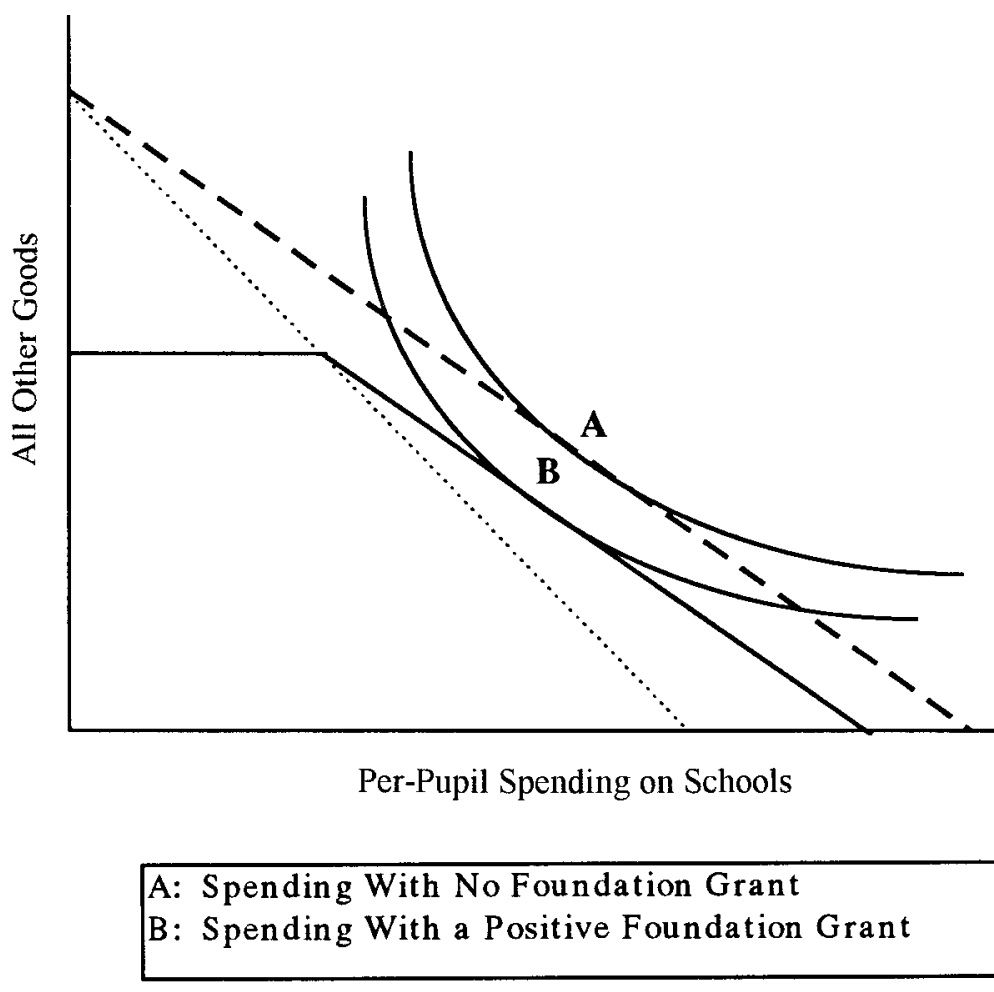

Figure 3. Residents of high-wealth districts (whose local tax price exceeds their state tax price for a dollar of education spending per pupil) are likely to prefer little or no state funding under a system of foundation grants with unlimited local supplementation.

from state sources while those from high-wealth districts will prefer that funding come from local sources. However, to the extent that voters from highwealth districts will be limited in the revenues they can raise locally, the only way that they can obtain the higher levels of school spending that they desire will be through positive state funding. Depending on the details of the system, the resulting level of state funding is likely to be somewhere in between those provided by the two other systems. In Figure 4, unlike Figure 3, the residents of high-wealth districts prefer the larger foundation grant (point A) to the smaller one (point B).

In addition, because some supplementation is allowed, residents of highdemand districts are likely to be closer to their optimum level of spending than they would be under a uniform foundation grant. Thus, while sacrificing equity relative to uniform state funding, a system of limited supplementation may be more acceptible politically than a pure state funding system, especially to residents of high-demand, high-wealth districts who are pushed far from their demand curve when no supplementation is allowed. (Of course, such residents would prefer a system with no foundation grants and complete local control even more, but this choice is unlikely to become available. One can also image combining the analyses of Figure 2 and Figure 4 to show circum- 


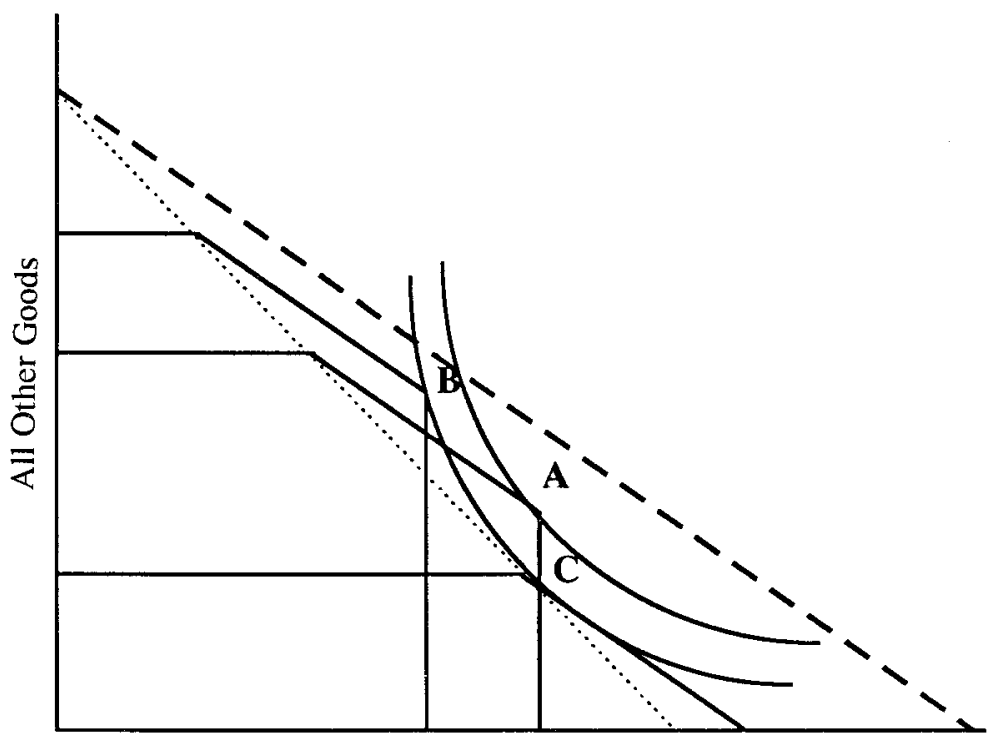

Per-Pupil Spending on Schools

A: Individual's Optimal

B: Too Little State Funding

C: Too Much State Funding

Figure 4. Under a system of state grants with limited local supplementation even residents of high-wealth districts are likely to prefer positive state funding levels.

stances under which voters would "jump" to a private school equilibrium in preference to limited supplementation. However, the set of circumstances under which this would happen will be smaller under limited supplementation than under uniform state finance.)

\section{Michigan}

In this light, two elements of the new system particularly stand out: the limited supplementation allowed in previously high-spending districts and the difference in foundation grant levels provided to the districts in general. Both of these elements arose from political pressures and the desire not to reduce funding to schools in any district while avoiding the fiscal impossibility of equalizing spending at a very high level. As it happens, both of these elements also tend to lead the high-spending districts to support a reasonably high basic foundation allowance, because by doing so, they can keep their spending about where they had previously shown they wanted it to be.

Michigan's supplementation is limited in two ways: Only some districts may supplement and each of those may supplement by a fixed dollar amount. The choice of $\$ 6500$ as the level of prior spending above which supplementation is permitted may contribute to maintaining the balance between high foundation grant levels and political stability. Figure 1 shows that the small number of 
districts that chose spending levels above $\$ 6500$ tended to choose levels well beyond this figure. Thus, the choice of $\$ 6500$ for the cutoff allows most districts with substantially greater demand than the median to supplement while retaining the benefits of a pure state funding system among the rest of the voters, most of whom are likely to receive close to their preferred level of school funding in a system of pure state finance. Overall, the supplementation element of the new system may then enhance the stability of the foundation grant level, although the different treatment of different districts may lead to other problems that we will discuss.

\section{Migration and Capitalization}

In the long run, the new system will have effects on the distribution of the population across districts and, via capitalization, on the value of property. After reform, an individual's tax price for schooling (except in the 28 districts that can supplement using local resources) is independent of district residence. The shift from local to state funding thus removes one benefit of living in a high-wealth district and may result in an incentive for residents to leave such districts, reducing property values ${ }^{17}$ Similarly, districts that used to have high millage rates will become more attractive, and people will tend to migrate toward them, bidding property values up. Because schooling accounts for such a large share of local public spending, these capitalization and migration effects are unlikely to be significantly mitigated via the finance of other public goods whose tax price still depends on local property wealth.

Capitalization and migration may prove to be especially important in districts (notably Detroit) that saw large reductions in millage rates and that have a significant stock of structurally sound housing with low-market prices. In this case, the reduction in millage rates will make housing in such districts more attractive to relatively high-income households, even if those households would not send their children to public schools. Basically, the reduction in millage rates in such districts will make private schools more attractive for potential residents, by reducing the cost of residing in the district.

We have not seen any trace of significant population redistribution in the wake of the reforms, and we have not yet been able to obtain any data that would allow us to evaluate the extent of capitalization of the tax changes. In the short and medium term, our instinct is to expect to see more capitalization than migration, because in general the tax liability associated with living in each district will have changed, but except for the lowest spending districts, school spending will not have changed. The incidence of these changes in property values will parallel that of the tax changes themselves, which we discussed earlier.

In the longer run, migration will put some stress on the state budget. In the range of $\$ 5000$ to $\$ 6500$ of spending per pupil (in 1993-1994) school spending is now independent of local taxes. Thus, the higher spending districts in this range will become relatively more attractive, and in some combination there

\footnotetext{
${ }^{17}$ If all nonresidential property is perfectly mobile, no benefit will have been derived in the first place, and there will be no such effect [Gordon, 1986]. The strong positive association between nonresidential SEV and spending per pupil in pre-reform Michigan (coefficient of 0.0076 with a $t$-statistic of 16.5), however, leads us to the conclusion that residents believe that on average the presence of nonresidential property reduces their tax price under the property tax, implying that such property is not perfectly mobile.
} 
will be increased school populations and higher property values in these districts. The movement of the school-age population away from lower spending districts towards higher spending districts will increase the average foundation grant, and hence increase the cost of school finance at the state level.

\section{Other Effects}

\section{Fiscal Substitution}

We expect to see fiscal substitution in formerly low-spending districts experiencing large increases in revenues for operating expenditures. A number of districts received rapid increases in operating revenues as a result of the reforms. Onaway, for example, saw an increase of over 23 percent between 1993-1994 and 1994-1995 and will continue to receive large increases for the next few years. Because the change in revenue is so great, the value of an extra dollar for operating expenditures will not be worth a dollar of tax reduction or other public spending in many of these districts. Attempts at fiscal substitution, disguising other expenditures (both school and nonschool) as school operating expenditures, is then likely. Anecdotal evidence suggests that this may already be happening, though reliable data on district expenditures is not yet available. In Onaway, for example, increased operating funds are being used partly for roofing projects and new buses. ${ }^{18}$

\section{Hold-Harmless Millages}

The 28 districts that can supplement their foundation grants are required to levy their supplemental (hold-harmless) millages on homestead property only, up to the point where the total millage on such property equals the 24 mills imposed on nonhomestead property. In over half of these districts, nonhomestead property accounts for more than half of all taxable property, implying a substantial increase in the marginal tax price of public schooling (assuming residents do not bear most of the tax burden on nonhomestead property in their district). Because of this increased tax price, in our earlier study, Courant, Gramlich, and Loeb [1995], we predicted that the demand for supplemental spending would be below the cap in a number of these previously high-spending districts. Contrary to our earlier predictions, in both years that the new system has been in effect, all districts that face apparent increases in their marginal tax prices have chosen to levy their maximum permitted amount. We do not have a very good explanation. It may be that voters are slow to notice their tax price change, especially since the actual millage rate is now lower than it was pre-reform. It may take a millage vote or two for voters to see that the marginal price of a dollar's worth of spending per pupil has increased.

\section{SAFI and the State Budget}

Much of the recent debate in Michigan has been about total state spending, and has taken the form of a technical debate about the value of the School Aid Fund Index (SAFI). As passed by the legislature in 1994, SAFI automatically determines spending per pupil, district by district, every year (subject to the vagaries of the 28 districts that have some choice over spending levels). Given

\footnotetext{
${ }^{18}$ Personal communication with the superintendent of Onaway schools.
} 
the political importance of school spending, it would not be surprising to discover that the legislature would like to reconsider the automatic nature of this process. This already seems to have happened. There appears to be enough ambiguity in how SAFI is measured, particularly in how the student population is measured, to get substantial disagreement over what level of funding SAFI implies. For the coming year, the executive branch arrived at a $\$ 113$ increase, while the legislature came up with $\$ 166$.

Because we do not have data available to determine what the "true" index should be, we do not know whether the legislature is simply trying to increase funds for K-12 or if the governor is trying to decrease them. Either (hence both) seems plausible. Michigan is currently enjoying both relative economic prosperity and relatively low taxes. In these circumstances voters may be willing to spend more on schools than dictated by the "true" level of SAFI. Not apparent in the current controversy, but potentially important over the longer run, is the possibility that voters may want to smooth school spending over the business cycle, spending more than SAFI allows during recessions and less during economic upturns. (As Fisher and Wassmer [1995] have noted, SAFI will make overall school spending much more responsive to the business cycle than were property tax revenues.) More fundamentally, the rigidity of an index such as SAFI does not allow for demand changes over time. For all of these reasons, it seems unlikely that the fully automatic application of SAFI to determine the level of school spending will survive politically, although the formula may continue to be a focal point for determining the annual basic foundation allowance.

\section{PROSPECTS AND CONCLUSIONS}

The new finance system was organized so that the vast majority of school students would have access to increased educational resources in the years immediately following reform. This was accomplished without bankrupting the state government by use of these clever tricks, the third of which is really a piece of good luck:

- The new system set the permitted amount of spending in all districts (and the actual amount, controlled by the state in the form of a foundation grant, in all but 28) to be at least somewhat higher than spending was in the last year prior to reform.

- Where the system permits districts to supplement the state-provided foundation grant, it limits the amount of supplementation allowed.

- Because of robust economic growth in the state during the period of reform, spending on schools could be increased, and overall taxes reduced, without significant real reductions in other parts of the state budget. The fiscal costs of the reforms have been easy to hide so far.

The first trick is the standard stuff of grandfather clauses: Set things up so that no one is worse off, at least for a while. In the context of school finance, where a history of local control and migration tended to put households somewhere near their demand curves prior to reform, the grandfather provision keeps everyone near their demand curves after reform, at least for a while-a feature that has much to recommend it. There has been very little in the way 
of general complaint that districts would like to tax themselves to spend more (at least so far) because the current spending levels are still close to those that the districts voluntarily chose when they could tax themselves to spend more. Over time, of course, this feature of the new system will become increasingly irrelevant, as people move, incomes change, and the like. Over time, then, we expect to see an increasing number of districts press the state for a restoration of local control, probably in the form of a right to supplement their foundation grants. To the extent that such districts are successful, depending on the amount of supplementation allowed, they may then also want to reduce the level of foundation grants in general, for the reasons we have discussed earlier. (Districts that would prefer lower spending, meanwhile, are unlikely to press for a reduction in their grants, as they would be very unlikely to get the difference in cash. Rather, they will become increasingly creative about finding ways to spend money that can be put in the school budget but that can achieve a variety of other purposes.)

The second innovative feature of the Michigan reform, limited supplementation permitted in some districts, holds some real promise as a policy that other states might want to try. One of the problems with foundation systems is that some districts want to spend more than the foundation grant. The usual solution to this problem that has been proposed in the economic literature, local supplementation, has the difficulty that high-demand communities may become a coalition for low foundation grants, compromising the ability of the foundation system to deliver equity. By limiting the amount of supplementation permitted by high-demand districts, these districts can be induced to support relatively high foundation grants, because this is the only way they can get anywhere near their preferred spending level. The mechanism design problem here is tricky: Allow "too much" supplementation and a low foundation grant will be chosen. Allow "too little," and the high-demand districts can opt for private education and, again, will not support much of a statewide foundation grant. We do not yet know how much room there is in-between, but there may be some: The question seems well worth exploring, and the exploration could be productively generalized to consider limited supplementation in all districts.

The reforms did a great deal to raise spending in low-spending districts, and the distributional effect of this change is surely progressive. The effect of the reforms on relatively low-income areas, most notably Detroit, was less positive. Detroit residents saw net tax increases, on average, and no spending increases. Moreover, urban districts generally face higher costs than do districts on average, and the reforms made no effort to compensate for these cost differences. ber of other elements of the Michigan reforms could also have been done better. Given that the property tax had to be cut for political reasons, we find it puzzling that the voters of the state chose to substitute the nondeductible sales tax rather than the deductible income tax. The cost to the state's taxpayers, as we have noted, is over 1 percent of state general revenues. For the usual reasons, we find assessment caps to be a poor way of reducing property taxes. They tend to lead to inefficiency in the housing market, as people become locked-in to both their current homes and low assessments following periods of inflation or growth in real property values. There is no good efficiency or equity reason for the tax system to favor people who happen to have been in their homes when property values were rising. The assessment cap will also put a strain on municipal tax bases. We appreciate the political necessity to 
cut property taxes, but it is unclear to us why an assessment cap was required in the context of an enormous cut in property tax rates.

Perhaps the most important feature of the Michigan reforms is that they happened, and they seem to be holding together. The political debate on schools has shifted from a discussion centered on how to cut property taxes to one that includes consideration of the content of the curriculum, the state's achievement testing program, and the structure of charter schools. All of this is to the good; the purpose of school finance is to provide the means to educate students, and it is our hope that the reforms will allow attention to be moved to what should have been the central policy issue all along.

\section{Some Clouds on the Distant Horizon}

In political terms, it is hard to see how the reforms could be more successful. The local property tax, the reduction of which has been the most difficult political issue in the state for a generation, has been dramatically reduced. Small, low-spending rural school districts that looked to be on the edge of bankruptcy enjoy fiscal health for the foreseeable future. The vast majority of districts are spending slightly more per pupil than they did pre-reform. Yet we see some clouds on the horizon:

- The loss of local control over spending will become increasingly noticeable over time, as the district-by-district demands for school spending diverge from the last pre-reform year (1993-1994) that was the basis for setting spending levels.

- With school spending determined largely by state-level revenue sources, the next recession is likely to make the trade-off between school spending and the rest of the state budget much more salient than was ever the case when the local property tax was the principal source of school finance.

- There is the possibility that voters in districts at the low end of the foundation grant distribution will notice that other districts are receiving up to $\$ 1500$ a year per pupil more than they are, and will press for a more uniform system of finance. Should this lead to a uniform foundation grant, residents of higher spending districts would almost certainly be forced off of their demand curves, leading to further pressure for local supplementation or other local control.

\section{Pressure for Increased Local Control}

The first problem will emerge gradually, and will lead, we think, to increasing pressure to permit local supplementation in more districts. Alternatively, if the charter school provisions associated with the reforms lead to significant growth of charter schools, it is possible that pressures for more local control will be accommodated by providing more support to the charter schools. ${ }^{19}$ The

\footnotetext{
${ }^{19}$ In conjunction with school finance reform, Michigan established a system of charter schools. The system is similar to a public school voucher system. Organizers of charter schools obtain a foundation grant from the state equal to the relevant district's foundation grant or $\$ 5500$ per pupil, whichever is less. (The local public school district loses the foundation grant attributable to students who go to a charter school, unless the charter school is run by the local district.) It is too early to tell what the quantitative importance of charter schools will be, and a number of court cases have established that charter schools will be subject to many of the same regulatory requirements (notably regarding certification of teachers) as public schools. The governor is a strong supporter of the charter school movement.
} 
balance of political power in the state when the issue of local control emerges will likely be very important. If the Democrats are in charge, one would expect to see an extension of local supplementation beyond the 28 districts now permitted to levy hold-harmless millages. If the Republicans are still in control and charter schools have proved to be successful, we would expect to see increased emphasis on the charter schools.

\section{The Business Cycle}

Michigan's economy is more prone than most to the business cycle, and both the School Aid Fund and the rest of the state budget will be quite responsive to an economic downturn. Thus, the time will likely come when either expenditures per pupil or the rest of state spending will have to fall in real terms. This will put stress on the polity, as recessions always do, but the stress will be compounded, relative to years past, for two reasons. First, the reduced importance of property taxes and increased importance of sales and income taxes make school finance (and total state and local revenues) more responsive to the business cycle than they used to be. Second, local school districts in the new system will not be able to compensate for reduced foundation grants by increasing local taxes. At the state level, Michigan has had a long history of accumulating surpluses (termed "rainy day funds") in good years, and spending them when times are tough. We would not be surprised to see an earmarked rainy day fund for the schools emerge. We would also not be surprised to see cyclically induced fiscal stress add to the pressures to permit local supplementation.

\section{Overall Stability of the Reforms}

In any case, we would be very surprised if the two key elements of the reformsreduced property taxation and centralization of financing (and hence of expenditure determination) - were reversed. For one thing, radical reform is generally unlikely, as witnessed by the 12 failed ballot proposals that preceded Michigan's reform. (We do not expect to see another game of chicken played out on the senate floor.) There is no constituency, now or on the horizon, for a return to greatly increased dependence on local property taxes statewide, and no other source of local finance has ever been made available to school districts. The main question for the longer term is the level of resources that can be sustained by a centralized system when it competes directly with the rest of the state budget. So far, the schools have done well, but in this matter, as in almost all elements of the Michigan political economy, we will need to see at least one full business cycle before we dare to predict the more distant future.

We are grateful to Edward M. Gramlich for comments on an earlier draft and for his collaboration in earlier phases of this project. We are also grateful to Robert Inman for helpful comments and encouragement. All errors and omissions are our own.

PAUL N. COURANT is Professor of Economics and Public Policy and Arthur F. Thurnau Professor at the University of Michigan.

SUSANNA LOEB is a Doctoral Candidate in Economics at the University of Michigan. 


\section{REFERENCES}

Addonizio, Michael F., C. Philip Kearney, and Henry J. Prince (1995), “Michigan’s High Wire Act," Journal of Education Finance 20(Winter), pp. 235-269.

Bergstrom, Ted, Daniel Rubinfeld, and Perry Shapiro (1982), "Micro-Based Estimates of Demand Functions for Local School Expenditures," Econometrica 50(September), pp. 1183-1205.

Courant, Paul N. and Daniel L. Rubinfeld (1987), “Tax Reform: Implications for the State-Local Public Sector," Journal of Economics Perspectives 1(Summer), pp. $87-100$.

Courant, Paul N., Edward Gramlich, and Susanna Loeb (1995), "A Report on School Finance and Educational Reform in Michigan," in T. A. Downes and W. A. Testa (eds.), Midwest Approaches to School Reform, Federal Reserve Bank of Chicago, pp. 5-33.

Cronin, Thomas E. (1989), Direct Democracy (Cambridge, MA: Harvard University Press).

Downes, Thomas A. (1992), "Evaluating the Impact of School Finance Reform on the Provision of Public Education: The California Case," National Tax Journal 45(4), pp. 405-419.

Downes, Thomas A. and Thomas F. Pogue (1994), “Adjusting School Aid Formulas for the Higher Cost of Educating Disadvantaged Students," National Tax Journal 47(March), pp. 89-110.

Fisher, Ronald C. and Robert W. Wassmer (1995), "Centralizing Educational Responsibility in Michigan and Other States: New Constraints on States and Localities," National Tax Journal 48(3), pp. 417-428.

Fullerton, Don and Diane Lim Rogers (1993), Who Bears the Lifetime Tax Burden (Washington, DC: The Brookings Institution).

Gordon, Roger H. (1986), "Taxation of Investment and Savings in a World Economy," American Economic Review 76, pp. 1086-1102.

Gramlich, Edward M. and Daniel L. Rubinfeld (1982), "Micro Estimates of Public Spending Demand Functions and Tests of the Tiebout and Median-Voter Hypothesis," Journal of Political Economy 90(31), pp. 536-560.

House Fiscal Agency (Michigan) (1994), "The Michigan School Aid Act Compiled and Appendices," October.

Ihlanfeldt, Keith R. (1982), "Property Tax Incidence on Owner-Occupied Housing: Evidence from the Annual Housing Survey," National Tax Journal 35(1), pp. 89-97.

Inman, Robert (1987), “Markets, Government, and the 'New' Political Economy,” in A. J. Auerbach and M. Feldstein (eds.), Handbook of Public Economics, Vol. 2 (Amsterdam: North-Holland).

Kearney, C. Philip (1994), A Primer on Michigan School Finance, Bureau of Accreditation and School Improvement Studies, School of Education, University of Michigan.

Ladd, Helen F. and John Yinger (1994), “The Case for Equalizing Aid,” National Tax Journal 47(1), pp. 211-224.

Loeb, Susanna (1996), "School Finance Reform: The Effects of Alternative State Finance Systems," Working Paper, University of Michigan.

Ratcliffe, Kerri, Bruce Riddle, and John Yinger (1990), “The Fiscal Condition of School Districts in Nebraska: Is Small Beautiful?” Economics of Education Review 9(1), pp. 81-99.

Romer, Thomas and Howard Rosenthal (1979), “The Elusive Median Voter," Journal of Public Economics 12, pp. 143-170.

Romer, Thomas and Howard Rosenthal (1982), "Median Voters or Budget Maximizers: Evidence from School Expenditure Referenda,” Economic Inquiry 20, pp. 556578. 
Rubinfeld, Daniel, Perry Shapiro, and Judith Roberts (1987), “Tiebout Bias and the Demand for Local Public Schools," The Review of Economics and Statistics 69(3), pp. 426-437.

Senate Fiscal Agency (Michigan) (1994), "Michigan School Finance Reform: Analysis of the Enacted School Finance/Education Reform Package."

Senate Fiscal Agency (Michigan) (1995), “1995 Statistical Report,” November 1995.

Senate Fiscal Agency (Michigan) (1996), Budget Status Report Issue 1996-1."

Silva, Fabio and Jon Sonstelie (1995), "Did Serrano Cause a Decline in School Spending?” National Tax Journal 48(2), pp. 199-216.

Slemrod, Joel and Jon Bakija (1996), Taxing Ourselves (Cambridge, MA: MIT Press).

Wortley, Jay and George Towne (1996), “Tax Changes in Michigan 1991 through 1995,” Senate Fiscal Agency, June. 